\title{
Letter from the Editors
}

We are delighted to present to you an interview with Professor Chris Bayly, the prominent specialist on Indian History, Imperial History and Global History. The editors are very grateful to Binu $M$. John for doing the interview. This issue contains four articles. Adam Clulow examines the role of Japanese mercenaries in the Ambonya Incident of 1623; Christian J. Koot analyses English policy on inter-imperial trade with the Dutch in the seventeenth-century Atlantic; Sandra Rebok investigates Alexander von Humboldt's travel diaries on colonial Spanish America; and Wim Ravesteijn brings us a study on the relationship between irrigation engineering and state formation in the Dutch East Indies. As always there is a very rich and extensive book review section, including review articles by David Northrup on slavery and the slave trade in the Atlantic World, and by Katalin Ferber on recent publications dealing with the opening of Japan.

As Itinerario enters its thirty-first year, we bid farewell to a substantial part of the team that has been responsible for the journal during the past three to four years. Henk Niemeijer, editor for many years and editor-in-chief since 2003, has done very much for the journal and introduced its current format and appearance. A pivotal role was also played by Karuna Sharma, as the editorial assistant during the period 2004-2006. Wim Klooster, David Henley, and Werner Thomas each did important work as editors. The same goes for Lennart Bes, who was responsible for the archival articles. The journal has benefited immensely from their work.

The Editors 